\title{
Analisis Fitokimia dan Aktivitas Antioksidan Pada Kulit Buah Jengkol (Pithecellobium Jiringga)
}

\author{
Wartono* \\ Prodi Pengolahan Hasil Hutan \\ Politeknik Pertanian Negeri \\ Samarinda \\ J1.Sam Ratulangi Kampus Gunung \\ Panjang, Samarinda Seberang, PO \\ BOX 192 Samarinda \\ Kalimantan Timur \\ wartomo63.phh@gmail.com \\ *Corresponding author
}

\author{
Mazmir \\ Prodi Pengolahan Hasil Hutan \\ Politeknik Pertanian Negeri \\ Samarinda \\ Jl.Sam Ratulangi Kampus Gunung \\ Panjang, Samarinda Seberang, PO \\ BOX 192 Samarinda \\ Kalimantan Timur \\ mazmir184@gmail.com
}

\author{
Farida Aryani \\ Prodi Pengolahan Hasil Perkebunan \\ Politeknik Pertanian Negeri \\ Samarinda \\ Jl.Sam Ratulangi Kampus Gunung \\ Panjang, Samarinda Seberang, PO \\ BOX 192 Samarinda \\ Kalimantan Timur \\ ary_ani02@yahoo.com
}

\begin{abstract}
Abstrak- Kulit buah jengkol merupakan limbah yang biasanya berada di tempat-tempat seperti pasar tradisional yang sampai saat ini belum ada pemanfaatannya secara khusus. Oleh karena itu diperlukan penelitian untuk mengetahui manfaat dan kandungan-kandungan dari limbah kulit buah jengkol tersebut. Tujuan penelitian ini untuk mengetahui kandungan fitokimia dan aktivitas antioksidan pada kulit buah jengkol (Pithecellobium jiringga). Kulit jengkol diekstraksi dengan metode maserasi menggunakan etanol pada suhu kamar, kemudian dilakukan pemekatan ekstrak menggunakan vacuum rotary evaporator sehingga diperoleh ekstrak kasar. Analisis fitokimia dilakukan untuk mengidentifikasi golongan senyawa metabolit sekunder yang meliputi flavonoid, alkaloid, tanin, saponin triterpenoid dan steroid. Untuk mengetahui aktivitas antioksidan dilakukan dengan variasi konsentrasi 3.12; $6.25 ; 12.5 ; 25 ; 50$ ppm untuk menghitung nilai $\mathrm{IC}_{50}$ yaitu konsentrasi contoh uji yang mampu menghambat $50 \%$ radikal bebas dimana DPPH (1,1-diphenyl-2picrylhidrazyl) digunakan sebagai radikal bebas. Hasil penelitian menunjukkan kulit buah jengkol memiliki kandungan fitokimia yaitu saponin, flavonoid, tanin, triterpenoid, alkaloid dan memiliki aktivitas antioksidan yang tergolong kategori kuat dengan nilai $\mathrm{IC}_{50} 29.24$ ppm. Sebagai kontrol positif digunakan Ascorbic Acid dengan nilai $\mathrm{IC}_{50} 2.8 \mathrm{ppm}$.
\end{abstract}

Kata kunci: Fitokimia, Kulit jengkol, aktivitas antioksidan, DPPH, $\mathrm{IC}_{50}$

\section{PENDAHULUAN}

Jengkol selama ini dimanfaatkan masyarakat adalah buahnya sebagai bahan makanan. Buah jengkol banyak dijumpai disetiap pasar tradisional yang ada di Indonesia. Kulit jengkol (Pithecellobium Jiringga) selama ini tergolong limbah organik yang berserakan di pasar tradisional dan tidak memberikan nilai ekonomis (Surya, 2017).
Antioksidan sangat bermanfaat bagi kesehatan dalam pencegahan proses menua dan penyakit degeneratif. Antioksidan dapat melawan radikal bebas yang terdapat dalam tubuh, yang didapat dari hasil metabolisme tubuh, polusi udara, cemaran makanan, sinar matahari, dsb. Mengkonsumsi antioksidan setiap hari baik berupa sediaan antioksidan maupun bahan alam yang mengandung antioksidan sangat perlu untuk mencegah stres oksidatif yang terjadi pada proses degeneratif.

Antioksidan terdiri dari dua macam yaitu antioksidan alami dan antioksidan sintetik. Antioksidan sintetik antara lain butyl hidroksilanisol (BHA), butyl hidroksitoluen (BHT), dan propol gallat. Efek penggunaan antioksidan secara berlebihan bagi kesehatan menyebabkan lemah otot, mual, pusing, dan kehilangan kesadaran. Sedangkan penggunaan pada dosis rendah secara terus menerus menyebabkan tomor kandung kemih, kanker sekitar lambung, dan kanker paru-paru (Cahyadi 2009).

Berdasarkan uraian diatas maka dilakukan penelitian untuk mengetahui potensi aktivitas antioksidan dari ekstrak etanol kulit jengkol terhadap radikal DPPH yang dinyatakan dalam $\mathrm{IC}_{50}$. Penelitian ini juga diharapkan dapat memberi informasi tentang manfaat dari kulit jengkol yang dapat digunakan sebagai alternatif dalam pengembangan obat-obat alami sebagai pencegah atau terapi terhadap penyakit degeneratif yang disebabkan oleh radikal bebas.

\section{STUDI PUSTAKA}

Para peneliti mencoba memanfaatkan kandungan senyawa dalam jengkol maupun kulitnya untuk digunakan dalam kehidupan. Senyawa yang mempunyai potensi sebagai antioksidan umumnya merupakan senyawa flavonoid, fenolik, dan alkaloid. Senyawa flavonoid dan polifenolbersifat antioksidan, antikanker 
antiseptic dan anti inflamasi (Nurussakinah, 2010).

Radikal bebas adalah suatu atom yang memiliki satu elektron tidak berpasangan dan bersifat reaktif sehingga cenderung bereaksi terus menerus membentuk radikal yang baru. Radikal bebas sangat berbahaya bagi tubuh manusia karena dapat merusak komponen-komponen sel tubuh seperti lipid, protein, dan DNA. Radikal bebas merupakan molekul yang tidak stabil dari luar maupun dalam tubuh yang secara perlahan dapat menimbulkan berbagai penyakit yang mengganggu kesehatan. Untuk menangani radikal bebas, dapat digunakan zat antioksidan yang dapat diperoleh baik dari tanaman maupun hewan. Antioksidan adalah senyawa yang memiliki peran penting dalam menjaga kesehatan karena kemampuannya menangkap molekul radikal bebas. Kemampuan untuk menghambat reaksi oksidatif dalam tubuh yang merupakan penyebab berbagai penyakit

Pada saat ini penggunaan antioksidan sintetis, seperti BHT (Butylated Hidroxy Toluene), BHA (Butylated Hidroxy Anisole), TBHA(Tertier Butylated Hidroxya Anisole), tidak direkomendasikan oleh badan pengawas obat dan makanan karena diduga dapat menimbulkan penyakit kanker (Carninigen Agen). Oleh karna itu, perlu dicari alternatif lain yang berasal dari bahan alam (Barus, 2009).

\section{METODE}

Bahan. Bahan baku yang digunakan dalam penelitian adalah Kulit Buah Jengkol (Pithecellobium jiringga). Bahan kimia yang digunakan meliputi etanol, aseton, dimetilsulfoksida (DMSO), aquades, larutan DPPH, (1,1-diphenyl-2-picrylhydrazyl), gallic acid, natrium hidroksida, asam asetat anhidrid, asam sulfat, asam klorida, timbal asetat, pereaksi dragendoreff, 1naphtol, pereaksi molisch, $\mathrm{H} 2 \mathrm{SO} 4$ pekat, $\mathrm{H} 2 \mathrm{O} 230 \%$, HCI 0,2 N, aquadest, dan larutan standar Ascorbic acid.

Alat Penelitian. Peralatan yang digunakan dalam penelitian ini adalah : pisau, blander, shaker, corong, rotary vacuum evaporator, spektrofotometer, beaker glass sebagai ukuran, gelas ukur, botol sampel, Cuvette, pipet pastur, pipet mikro, dan tabung reaksi.

\section{Prosedur Penelitian}

Penelitian ini diawali dengan persiapan bahan penelitian berupa sampel kulit buah segar yang baru lepas dari buahnya. Selanjutnya kulit jengkol dirajang menjadi ukuran kecil menggunakan pisau, kemudian dikeringkan pada suhu kamar. Setelah kering kemudian sampel diblander hingga menjadi serbuk simplisia dan selanjutnya siap untuk diekstrak.

\section{Proses Ekstraksi}

Metode ekstraksi yang digunakan yaitu ekstraksi dingin menggunakan pelarut etanol. Ekstraksi dilakukan dengan melarutkan simplisia, dengan rasio serbuk : pelarut (1:10). Ekstraksi dilakukan dengan merendam sampel dengan etanol, lalu dikocok menggunakan shaker, selama 48 jam pada temperatur ruangan. Proses selanjutnya dilakukan penyaringan untuk memisahkan ekstrak dengan bahan tumbuhan.
Setelah itu ekstrak dipekatkan menggunakan alat vacuum rotary evaporator pada suhu $30-40^{\circ} \mathrm{C}$, sehingga diperoleh ekstrak kasar.

\section{Pengujian Fitokimia}

Pengujian fitokimia dilakukan dengan uji perubahan warna yang mengaju pada Harborne (1987) dan Kokate (2001) untuk menguji adanya senyawa aktif yang meliputi :

a. Pengujian alkaloid (Kokate, 2001)

identifikasi dilakukan dengan menggunakan larutan Dragendorff. Tahapan pembuatan larutan Dragendorff sebagai berikut :

(1) Larutan I : 0,5 g bismut (III) nitrat $+6 \mathrm{ml}$ asam asetat dan $24 \mathrm{ml}$ aquades.

(2) Larutan II : $12 \mathrm{~g}$ kalium iodida $+30 \mathrm{ml}$ aquades.

(3) Larutan I + Larutan II (1 ml : 1ml).

(4) $1 \mathrm{ml}$ larutan campuran ditambah $2 \mathrm{ml}$ asetat dan $10 \mathrm{ml}$ aquades, selanjutnya larutan siap untuk digunakan.

(5) Sebanyak $5 \mathrm{ml}$ ekstrak ditambahkan $2 \mathrm{ml}$ HCI, kemudian dimasukkan $1 \mathrm{ml}$ larutan Dragendorff. Perubahan warna larutan menjadi jingga atau merah mengindikasikan bahwa ekstrak mengandung alkaloid.

b. Pengujian flavonoid (Kakote, 2001)

Sebanyak $1 \mathrm{ml}$ ekstrak tumbuhan diberikan beberapa tetes natrium hidroksida encer $(\mathrm{NaOH} 1 \%)$ munculnya warna kuning yang jelas pada larutan ekstrak dan menjadi tidak berwarna setelah penambahan asam encer (HCI $1 \%$ ) mengindikasikan adanya flavonoid.

c. Pengujian saponin (Harborne, 1987)

Pengujian dilakukan dengan memasukkan $10 \mathrm{ml}$ air panas kedalam tabung reaksi yang beisi $1 \mathrm{ml}$ sampel uji yang telah dilarutkan dalam aseton. Selanjutnya larutan didinginkan dan dikocok selama 10 detik. Terbentuknya buih selama kurang lebih selama 10 menit dengan ketinggian 1-10 cm dan tidak hilang bila ditambahkan 1 tetes HCI $2 \mathrm{~N}$ menandakan bahwa ekstrak yang diuji mengandung saponin.

d. Pengujian tanin (Kakote, 2001)

Pengujian dilakukan dengan memasukkan $10 \mathrm{ml}$ larutan ekstrak kedalam tabung reaksi dan ditambahkan larutan timbal asetat $(\mathrm{CH} 3 \mathrm{COO}) 2 \mathrm{~Pb}$ $1 \%$. Tanin dinyatakan positif apabila pada reaksi terbentuk endapan kuning.

e. Pengujian triterpenoid dan steroid (Harborne, 1987)

Identifikasi dilakukan dengan melakukan campuran asam asetat ahidrid dan asam sulfat pekat yang biasa dikenal pereaksi Liebermann-Burchard. Pada pengujian ini 10 tetes asam asetat ahidrid dan 2 tetes asam sulfat pekat ditambahkan secara berurutan kedalam $1 \mathrm{ml}$ sampel uji yang telah dilarutkan dalam aseton. Selanjutnya sampel uji dikocok dan dibiarkan beberapa menit. Reaksi yang terjadi diikuti dengan perubahan warna, apabila terlihat warna merah dan ungu maka uji dinyatakan positif untuk triterpenoid 
dan apabila terlihat warna hijau dan biru maka uji dinyatakan positif pada streroid.

\section{Pengujian Aktivitas Antioksidan}

Pengujian aktivitas antioksidan dilakukan dengan mengacu pada metoda Arung (2008). Menggunakan spektrofotomerer pada suhu kamar $\left(25^{\circ} \mathrm{C}\right)$ dengan panjang glombang $514 \mathrm{~nm}$ dan larutan DPPH $(1,1-$ diphenyl-2-picrylhydrazyl) digunakan sebagai radikal bebas, serta Ascorbic acid sebagai kontrol positif.

Ekstrak sample sebanyak 1,5 mg dilarutkan dalam 1 $\mathrm{ml}$ DMSO sehingga diperoleh larutan dengan konsentrasi $50 \mu \mathrm{g} / \mathrm{ml}$ (konsentrasi $50 \mu \mathrm{g} / \mathrm{ml}=33 \mu \mathrm{L}$ ekstrak $+467 \mu \mathrm{L}$ etanol dan $500 \mu \mathrm{L} \mathrm{DPPH})$. Sampel diinkubasi selama 20 menit dengan ruangan yang minim cahaya pada suhu ruangan. Aktifitas antioksidan ditentukan melalui dekolorisasi dari DPPH dari panjang gelombang $514 \mathrm{~nm}$ menggunakan UV-Vis spektrofotometer. Pengujian dilakukan dengan konsentrasi 50 ppm untuk skrining awal konsentrasi dilakukan penurunan menjadi $6,25 \mu \mathrm{g} / \mathrm{ml}, 12,5 \mu \mathrm{g} / \mathrm{ml}$ dan $25 \mu \mathrm{g} / \mathrm{ml}$ terhadap penghambatan minimal $50 \%$ terhadap sampel DPPH untuk mendapatkan nilai $\mathrm{IC}_{50}$ yang berguna untuk menggambarkan besarnya konsentrasi ekstrak uji yang dapat menangkap radikal bebas DPPH sebesar 50\% melalui persamaan garis linear yang menyatakan hubungan antara konsentrasi ekstrak uji (x) dengan aktivitas penangkap radikal bebas (y), Ascorbic acid digunakan sebagai kontrol positif.

Aktivitas antioksidan dari ekstrak sampel ditentukan berdasarkan persentase daya hambat relatif terhadap kontrol yang menggunakan persamaan sebagai berikut : (Cefarelli et al.,2006).

$$
\% \text { Inhibisi }=\frac{A D P P H-A \text { Sampel }}{A D P P H} \times 100
$$

Tabel I. Tingkat Kekuatan Antioksidan dengan Metode DPPH [9] (Pharmascience, 2019)

\begin{tabular}{|c|c|}
\hline Intensitas & Nilai IC50 (ppm) \\
\hline Kuat & $<100$ \\
Sedang & $101-250$ \\
Lemah & $250-500$ \\
Tidak Aktif & $>500$ \\
\hline
\end{tabular}

\section{HASIL DAN PEMBAHASAN}

\section{Fitokimia}

Hasil yang diperoleh seperti yang terlihat pada tabel 2 sebelumnya memperlihatkan bahwa kulit buah jengkol memiliki potensi fitokimia yang cukup baik. Berdasarkan uji fitokimia yang dilakukan, didapatkan bahwa alkaloid, flavonoid, tanin, saponin dan tritervenoid terdeteksi pada sampel yang diteliti.

Flavonoid terdeteksi pada kulit karna senyawa tersebut adalah kelompok senyawa polyphenol yang secara alami terdapat pada buah-buahan, sayuran, kacang-kacangan, biji, bunga, daun, kulit, pohon, dan lain-lain (Totok, 2013). Flavonoid termasuk salah satu klompok senyawa aromatik yang termasuk polifenol dan mengandung antioksidan.

Flavonoid adalah senyawa yang terdiri dari 15 atom karbon yang umumnya tersebar didunia tumbuhan. Flavonoid tersebar luas ditanaman mempunyai banyak fungsi. Flavonoid adalah figmen tanaman untuk memproduksi warna bunga merah atau biru figmentasi kuning pada kelopak yang digunakan untuk menarik hewan penyerbuk. Manfaat flavonoid antaralain untuk melindungi struktur sel, meningkatkan efektifitas vitzmin $\mathrm{C}$, anti inflamasi, mencegas kropos tulang dan sebagai antibiotik (Haris, 2011).

Alkaloid adalah sebuah golongan senyawa basa bernitrogen yang kebanyakan hiterosiklik dan terdapat pada tumbuhan, asam amino, peptida, protein, nukletoid, asam nukleik, gula amino dan antibiotik biasanya tidak digolongkan sebagai alkaloid.

Saponin adalah jenis senyawa kimia yang berlimpah dalam berbagai spesies tumbuhan senyawa ini merupakan glikosida amfipatik yang dapat mengeluarkan busa jika dikocok dengan kencang didalam larutan dan busanya bersifat setabil tidak mudah hilang.

Tanin biasanya dijumpai pada hampir semua tumbuhan hijau dan biasanya terdapat lebih banyak pada kulit kayu. Hasil pengujian menunjukkan ekstrak sempel mengandung tanin. Semain banyak kandungan tanin maka semakin besar aktivitas antioksidannya karna tanin tersusun dari senyawa polifenol yang memiliki aktivitas penangkap radikal bebas (Lenny., 2006). Tanin merupakan senyawa aktif metabolit sekunder yang diketahui mempunyai beberapa khasiat yaitu sebagai astringen, anti diare, anti bakteri, dan antiolsidan.

Triterpenoid adalah salah satu senyawa metabolit sekunder yang terkandung dalam tanaman, senyawa tersebut dapat dijumpai pada bagian akar, batang, daun, buah, maupun biji tanaman. Sebagian besar senyawa triterpenoid memiliki kegiatan fisiologi yang menonjol sehingga dalam kegiatan sehari-hari banyak digunakan sebagai obat seperti untuk pengobatan penyakit diabetes, gangguan menstruasi, patukan ular, gangguan kulit, kerusakan hati dan malaria. Sedangkan tumbuhan yang mengandung senyawa triterpenoid terdapat nilai ekologi karna senyawa ini bekerja sebagai antifungus, insektisida, anti pemangsa, anti bakteri dan antivirus.

\section{Antioksidan}

Hasil penelitian yang disajikan pada tabel 3 terlihat bahwa $\mathrm{IC}_{50}$ kulit buah jengkol sebesar 29.24 ppm. Nilai $\mathrm{IC}_{50}$ merupakan konsentrasi senyawa antioksidan yang memberikan inhibisi sebesar 50\% yang artinya pada konsentrasi tersebut antioksidan dapat menghambat radikal bebas sebesar 50\%. Pada kontrol positif yang digunakan Ascorbic Acid dengan $\mathrm{IC}_{50}$ sebesar 2.80 ppm, aktivitas antioksidannya yang sangat kuat karena, merupakan senyawa yang sudah murni. Namun demikian aktivitas antioksidan kulit jengkol termasuk dalam kategori kuat. Antioksidan diindikasikan kuat jika nilai IC50 semakin rendah, hal ini dikemukakan 
oleh Jun et.al. (2003) dimana nilai $\mathrm{IC}_{50}$ kurang dari 100 ppm dikatakan kuat, 100ppm sampai 250 ppm sedang, 250 ppm sampai 500 ppm lemah, lebih dari 500 ppm tidak aktif. Analisis aktivitas antioksidan ekstrak kulit buah jengkol. Menggunakan metode DPPH dengan Ascorbic Acid sebagai kontrol positif, dimana parameter dari metode ini adalah nilai Inhibition Concrentation $\left(\mathrm{IC}_{50}\right)$ yaitu nilai konsentrasi yang dapat meredam 50\% aktivitas radikal bebas dimana DPPH berfungsi sebagai radikal bebas. Hubungan konsentrasi larutan ekstrak kulit jengkol dan Ascorbic acid sebagai kontrol positif terhadap penghambatan DPPH ditunjukkan pada gambar 2 dan gambar 3. Dimana pada grafik terjadi peningkatan penghambatan DPPH sering dengan kenaikan konsentrasi ekstrak

\begin{tabular}{|c|c|}
\hline Metabolit Sekunder & Sampel Kulit Jengkol \\
\hline Alkaloid & Terd \\
\hline Flavonoid & Terdeteksi \\
\hline Saponin & Terdeteksi \\
& Terdeteksi \\
\hline Triterpen/Steroid & Triterpenoid \\
\hline & \\
\hline & \\
\hline
\end{tabular}

Tabel 2. Hasil Analisis Fitokimia

Tabel 3. Nilai IC50 Kulit Jengkol dan Ascorbic Acid

\begin{tabular}{|c|c|c|}
\hline & IC $_{50}$ & $\begin{array}{c}\text { Persamaan Garis } \\
\text { Regresi Linier }\end{array}$ \\
\hline $\begin{array}{c}\text { Kulit } \\
\text { Jengkol }\end{array}$ & 29.24 & $\mathrm{y}=0.9603 \mathrm{x}+21.921$ \\
\hline $\begin{array}{c}\text { Ascorbic } \\
\text { Acid }\end{array}$ & 2.80 & $\mathrm{y}=20.725 \mathrm{x}+8.108$ \\
\hline
\end{tabular}

Perhitungan nilai $\mathrm{IC}_{50}$ sample ekstrak kulit buah jengkol

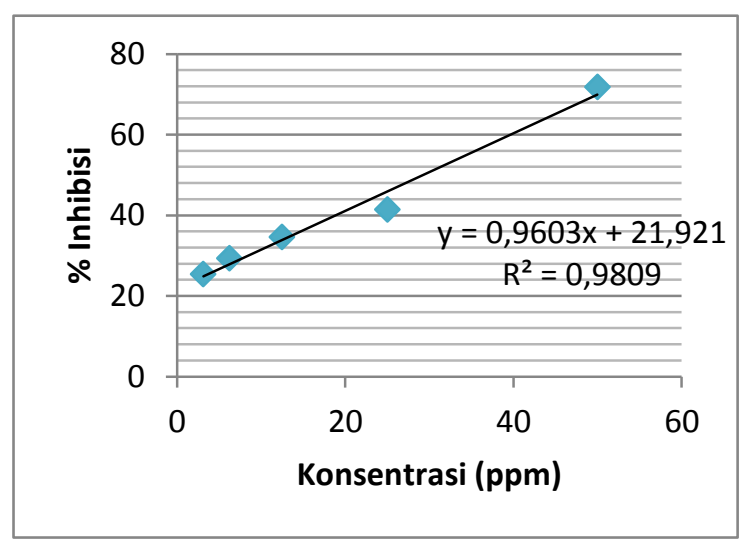

Gambar 1.Kurva Regresi Linier Ekstrak Kulit Jengkol

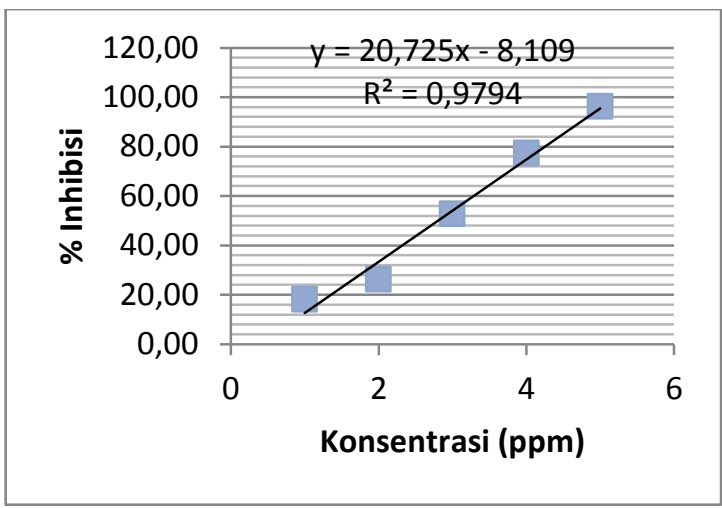

Gambar 2. Kurva Regresi Linier Ascorbic Acid

Antioksidan merupakan molekul yang mampu memperlambat atau mencegah proses oksidasi molekul lain. Oksidasi adalah reaksi kimia yang dapat menghasilkan radikal bebas, sehingga memicu reaksi berantai yang dapat merusak sel. Salah satu senyawa yang terkandung dalam kulit jengkol adalah flavonoid. Flavonoid merupakan senyawa fenol tergolong sebagai salah satu metabolit sekunder pada tumbuhan yang berfungsi sebagai antioksidan

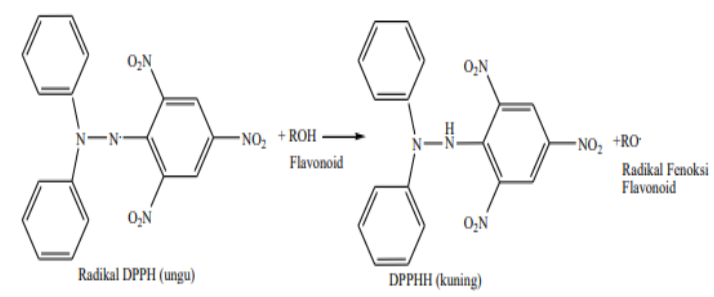

Gambar 3. Reaksi Antara DPPH dengan Flavonoid (Amic, et all.2003)

Flavonoid dapat beraksi sebagai antioksidan dengan menangkap radikal bebas melalui pemberian atom hidrogen pada radikal tersebut. Kemampuan flavonoid untuk menangkap radikal DPPH dilukiskan sebagai 
reaksi yang tertera pada Gambar 9. Radikal fenoksi flavonoid ini distabilkan oleh delokalisasi elektron yang tidak berpasangan di sekitar cincin aromatis. Stabilitas radikal fenoksi flavonoid (RO.) akan mengurangi kecepatan perambatan (propagasi) autooksidasi reaksi berantai.

Flavonoid adalah senyawa polifenol (mengandung beberapa gugus hidroksil fenolik) dan beberapa senyawa lainnya. Sifat kimia inilah yang mendasari banyaknya efek farmakologi secara in vitro yang berkesan dari senyawa ini. Khususnya, flavanoid mampu untuk mengkompleks dengan ion logam, bekerja sebagai antioksidan dan berikatan dengan protein seperti enzim dan protein struktural (keistimewaan terakhir inilah yang dapat juga menjelaskan kemampuan dari flavonoid untuk meningkatkan kemampuan dari jaringan konektif). Sifat antioksidan dari flavonoid secara in vitro telah menjadi fokus utama dari kebanyakan penelitian selama akhirakhir ini. Kemampuan dari flavonoid untuk mengkompleks dengan ion logam seperti besi yang memungkinkan menambah efek antioksidannya pada keadaan khusus ini. Yang paling khusus adalah kemampuan dari flavonoid untuk menghambat oksidasi yang dibantu oleh makrofag dari LDL dengan demikian menunjang atherogenesis. Sifat antioksidan dari flavonoid dapat juga menunjang efek antiinflamasi dan antiplatelet dan dikaitkan bukan hanya dari sifat strukturnya tapi juga kemampuaanyya untuk berinteraksi dan berpenetrasi dengan lapisan lipid dari membrane sel. Flavonoid meredam radikal nitrit oksida, anion superoksida, dan oksigen singlet. Seperti kebanyakan antioksidan lainnya, flavonoid juga dapat bekerja seperti prooksidan pada keadaan tertentu (Syarif et al 2015).

Keberadaan tanin juga berpengaruh terhadap aktivitas antioksidan. Berbeda dengan flavonoid, tanin adalah salah satu golongan senyawa polifenol yang juga banyak dijumpai pada tanaman. Tanin dapat didefinisikan sebagai senyawa polifenol dengan berat molekul yang sangat besar yaitu lebih dari $1000 \mathrm{~g} / \mathrm{mol}$ serta dapat membentuk senyawa kompleks dengan protein. Struktur senyawa tannin terdiri dari cincin benzena (C6) yang berikatan dengan gugus hidroksil ($\mathrm{OH})$. Tanin memiliki peranan biologis yang besar karena fungsinya sebagai pengendap protein dan penghelat logam. Oeh karena itu tannin diprediksi dapat berperan sebagai antioksidan biologis (Noer,et al 2018)

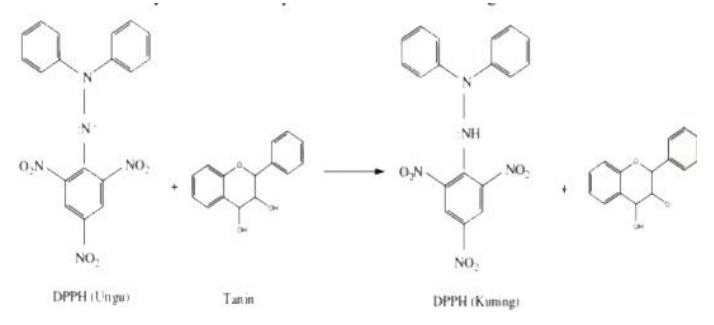

Gambar 4. Reaksi DPPH Dengan Tanin
Senyawa dari golongan alkaloid juga berperan sebagai antioksidan. Penelitian yang dilakukan oleh Dalimunthe (2018) terhadap kayu litsea menyatakan bahwa fraksi dan senyawa alkaloid memiliki aktivitas antioksidan

\section{KESIMPULAN}

Berdasarkan hasil penelitian yang dilakukan menunjukkan bahwa ekstrak kulit buah jengkol memiliki kandungan fitokimia dan aktioksidan yang baik. Khusus untuk aktivitas antioksidan, kulit buah jengkol dapat dijadikan sebagai salah satu sumber antioksidan alami karena memiliki potensi antioksidan yang tergolong kuat sama seperti kontrol positif Ascorbic Acid.

\section{DAFTAR PUSTAKA}

Adrianta.A. Aktivitas Antioksidan Daun Magenta (Peristrophe bivalvis (L.) Merr) SebagainSalah Satu Kandidat Pengobatan Bahan Berbasis Herbal Serta Bioaktivitasnya Sebagai Analgetik. Jurnal Ilmiah Medicamento $\bullet$ Vol.6 No.1•2020•ISSN-e: 2356-4818 33

Amic DD, Beslo D, and Trinajstic. Structure-radical scavenging activity relationship of flavonoids. Croatia Chem.Acta. 2003.

Ardiansyah. 2007 Antioksoidan dan Peranannya bagi Kesehatan www.Beriteiptek.com 14 (1) 1-7

Arung ET, Muladi S, Sukaton E, Shimizu K and Kondo R. (2008). Artocarpin, a promising compound as whitening agent and anti-skin cancer. J Trop Wood Sci Technol, 6, 33-36.

Cahyadi, Wisnu.2009, Bahan Tambahan Pangan, Jakarta: Bumi Aksara.

Cefarelli G, Abrosca BD, Fiorentino A, Izzo A, Mastellone C, Pacifica S and Piscopo V. (2006). Free-radical scavenging and antioxidant activities of secondary metabolites from reddened cv. Annurca apple fruits. J Agric Food Chem, 54(3)

Dalimunthe.A, Hasibuan.P.A.Z, Silalah.j, Sinaga.S.F,Satria.D(2018). Oriental Journal Chemistry Vol 34, No.(2)

Barus, P., Pemanfaatan Bahan Pengawet dan Antioksidan Alami pada Industri BahanMakanan, Pidato Pengukuhan Jabatan Guru Besar Tetap Dalam Bidang Ilmu Kimia Analitik Pada Fakultas MIPA diucapkan di Hadapan Rapat Terbuka Universitas Sumatra Utara 3.

Junaidi.L(.2007). Antioksidan Alami: Sumber, Kimia, dan Teknologi Ekstraksi. Warta IHP/J.of AgroBased Industry. Vol 24 No.2. Desember, pp 5269.

Kokate CK. (2001). Pharmacognosy. 16th ed. Nirali Prakasham, Mumbai, India.

Harborne, J.B. 1987. Metode Fitokimia (Terjemah). Terbitan Ke-2 Penerbit ITB. Bandung. 
Lenny, S. 2006. Senyawa Flavonoida, Fenilfropanoida dan Alkaloida. Karya Ilmiah. Fakultas Matematika dan Ilmu Pengetahuan Alam. Universitas Sumatra Utara,Medan.

Noer.S, Rosa.D.P, Efri.G, 2018. Penetapan Kadar Senyawa Fitokimia (Tanin, Saponin, dan Flavonoid Sebagai Kuersetin) pada Ekstrak Daun Ungu (Ruta angustifolia L.)

Nurussakinah, 2010. Skrining Fitokimia dan Uji Aktivitas Antibakteri Ekstrak Kulit Buah Tanaman Jengkol (Pithecellobium jiringga (Jack) Prain Terhadap Bakteri Streptococus mutans, Staphylococus aureus, dan Escherica coli, Skripsi,Fakultas Farmasi, USU, Medan. ISSN 2477-2089

Salusu, H., Ariani, F., Obeth, E., Rayment, M., Budiarso, E., Kusuma, I., \& Arung, E. 2017. Phytochemical Screening and Antioksidant Activity of Selekop (Lepisanthes amoena) Fruit. AGRIVITA, Journal Science, 39(2), 214-218. Doi: 10.17503/agrivita.v39i2.810

Surya.A.2017. Aktivitas antioksidan Ekstrak Kulit Jengkol (Pithecellobium jiringa) Dengan Tiga Pelarut Yang Berbeda Kepolaran. Jurnal Rekayasa Sistem Industri.

Syarif R.A, Muhajir, Aktsar R.A, Abd.M. Jurnal Fitofarmaka Indonesia, Vol 2 No 1 Pharmascience,2019-ppjp.uml.ac.id page 8.

Winarsi H.2007. Antioksidan Alami dan Radikal Bebas. Kanisius Yogyakarta. 